Article

\title{
Co-Benefits of Household Waste Recycling for Local Community's Sustainable Waste Management in Thailand
}

\author{
Amornchai Challcharoenwattana ${ }^{1,2, \dagger}$ and Chanathip Pharino $2,3, \uparrow, *$ \\ 1 International Postgraduate Programs in Environmental Management, Graduate School, \\ Chulalongkorn University, Bangkok 10330, Thailand; E-Mail: Amornchai.c@student.chula.ac.th \\ 2 Center of Excellence on Hazardous Substance Management (HSM), Chulalongkorn University, \\ Bangkok 10330, Thailand \\ 3 Department of Environmental Engineering, Faculty of Engineering, Chulalongkorn University, \\ Bangkok 10330, Thailand
}

$\dagger$ These authors contributed equally to this work.

* Author to whom correspondence should be addressed; E-Mail: Chanathip.p@chula.ac.th; Tel.: +66-2-218-6668; Fax: +66-2-218-6666.

Academic Editor: Yasuhiro Fukushima

Received: 27 February 2015 / Accepted: 28 May 2015 / Published: 9 June 2015

\begin{abstract}
The study aimed to evaluate co-benefits in term of GHG reduction, and avoided landfill costs by implementing a community-based management (CBM) program for municipal solid waste (MSW). Two towns of peri-urban settlement in Thailand were investigated in case studies to compare eco-performance between the towns with and without implementation of the CBM program. MSW mass flows together with MSW utilization records were analyzed based on data in year 2013. Climate co-benefits from waste utilization activities were examined. Results from the study indicated that waste banks in the CBM program can effectively divert most of recyclables from entering landfills. The performance of "waste bank - recyclable recovery program" recycling rate from the case study with CBM is $172.20 \mathrm{~kg}$ per member per year, which is about $926 \%$ higher than average CBMs with MSW recycling in Thailand, and the success of CBM can be attributed to its curbside pickup service and fair-pricing of recyclables. The study also found that if the town decided to divert wastes from landfilling, carbon intensity of the MSW system would be 0.47 tons of $\mathrm{CO}_{2}$-eq per ton of collected MSW. The landfilling cost would be approximately 7.41 USD per ton of MSW as landfilling cost. With CBM programs, current MSW reutilization rate has achieved $9.68 \%$ of generated waste, and $16.80 \%$ of GHG emission has been avoided, along
\end{abstract}


with a reduction in landfill costs of $11.57 \%$. Two scenarios of waste utilization in Thailand were explored and compared, in terms of which scenarios yielded the highest co-benefits. The study demonstrates that by allowing local mechanism and community involvement programs to develop with operational waste banks, the efficiency of collecting recycling wastes increased. A similar system can be applied to other communities in other countries.

Keywords: mass balance; community-based management; recycling; municipal solid waste (MSW); landfilling cost; Thailand

\section{Introduction}

\subsection{Problems of Traditional MSW Management Practices}

Over the last few decades, negative impacts of landfill has become one of the major causes of environmental quality deterioration, particularly of worsening of groundwater quality, poor air quality from emitted gases and noxious odors, and worsening climate change impact [1-3]. Not surprisingly, employing landfill has become a less preferred MSW management (MSWM) technique. Moreover, stakeholders who live around landfills often suffer from deteriorated aesthetic and living quality in their neighborhood [4] and depressed property value [5,6]. The pressure of finding alternative means to handle MSW continues to challenge the capability of the MSWM system. Under the presence of urbanization, MSW generation rates have been found to accelerate along with increases of population size and wealth [7]. MSW composition has also changed according to various stages of urbanization. Generally, MSW composition in a less urbanized town tends to contain mostly food wastes while a more urbanized town tends to contain more diverse waste with a rising proportion of paper and plastic wastes [8].

Promoting MSW separation and recycling has become one of approaches to reduce MSW landfilling. Many countries, e.g., Japan, South Korea and the USA, approach the rising MSW generation through mandating waste separation and charging a relatively higher fee for landfilling MSW as a deterrence of landfilling mixed and unsorted wastes. The strategies involve at-source waste separation of recyclables from the regular wastes to minimize relatively high MSW disposal fees. There are, however, cases of waste generators outsmarting the volume-based MSW pricing system by compacting their refuses to reduce disposal cost [9]. Also, some MSW generators illegally dispose their refuses on neglected spaces or in neighbors' trash containers $[10,11]$. Hence, alternative modes to promote MSW separation may yield better results in term of recycling efficiency.

Thailand, like many other developing countries, is also facing problems of rising MSW generation. The trend continues to grow upward according to Thailand's Pollution Control Department [PCD] [12]. Daily MSW generation rates were found to be at $0.91 \mathrm{~kg}$ per capita in the smallest towns, classified by Thailand's Department of Local Administration where population size is lower than 5000 , to $1.89 \mathrm{~kg}$ per capita in fully urbanized towns, classified by Thailand's Department of Local Administration where population size is higher than 50,000. Table 1 suggests that Thailand's MSW compositions are also similar to other developing countries whereby organic wastes are the dominating waste type in all town sizes. Plastic and paper, however, gain a higher share of the waste stream in more urbanized towns. 
Public finances for MSWM often fail to provide and enforce incentives for MSW separation and recycling. From Table 2, the majority of towns in Thailand still employ unsounded disposal methods as alternatives, i.e., open dumping or open burning. This is because of the benefits of having relatively lower out-of-pocket cost as compared to other more advanced MSWM methods [8]. Environmental impact assessment (EIA) for landfill construction in Thailand is not required [Notification of the Ministry of Natural Resources and Environment dated 24 April B.E. 2555 (2012)] while some MSWM technologies, e.g., incinerator with electricity generator with $10 \mathrm{MW}$, are required to conduct an EIA. Despite relatively more relaxed rules for landfill chartering, many landfills, however, often face strong oppositions from stakeholders. For example, in 2012, seven out of 121 sanitary landfills in Thailand were put on suspension or unable to be commenced due to protests and legal proceedings [12].

Table 1. Composition of MSW in developing countries and selected cities.

\begin{tabular}{|c|c|c|c|c|c|c|c|}
\hline Locations & $\begin{array}{c}\text { Generation Rate } \\
\text { (kg/capita·day) }\end{array}$ & $\begin{array}{c}\text { Organic } \\
(\%) \\
\end{array}$ & $\begin{array}{c}\text { Paper } \\
(\%)\end{array}$ & $\begin{array}{c}\text { Plastic } \\
(\%)\end{array}$ & $\begin{array}{c}\text { Glass } \\
(\%)\end{array}$ & $\begin{array}{c}\text { Metal } \\
(\%)\end{array}$ & $\begin{array}{c}\text { Other } \\
(\%)\end{array}$ \\
\hline Average Low Income Countries [8] & 0.6 & 64 & 5 & 8 & 3 & 3 & 17 \\
\hline Average Lower middle income Countries [8] & 0.79 & 59 & 9 & 12 & 3 & 2 & 15 \\
\hline Average Upper middle income Countries [8] & 1.2 & 54 & 14 & 11 & 5 & 3 & 13 \\
\hline Average High Income Countries [8] & 2.1 & 28 & 31 & 11 & 7 & 6 & 17 \\
\hline Bangkok, Thailand [13] & 1.57 & 50 & 11.3 & 22.5 & 2.7 & 1.7 & 12 \\
\hline Phnom Penh, Cambodia [14] cited in [15] & 0.74 & 69.6 & 6.4 & 15.5 & 1.2 & 0.6 & 7 \\
\hline Delhi, India [16] & 0.5 & 38.6 & 5.6 & 6 & 1 & 0.2 & 49 \\
\hline Beijing, China [17] & 0.85 & 63.4 & 11.1 & 12.7 & 1.8 & 0.3 & 11 \\
\hline
\end{tabular}

Table 2. Statistics of MSWM methods in Thailand [18].

\begin{tabular}{llcc}
\hline \multicolumn{1}{c}{ MSWM Methods } & \multicolumn{1}{c}{ Details } & Numbers of Sites \\
\hline & Sanitary/Engineered landfill & 73 \\
& Controlled Dump & 367 \\
Compliance to & Incinerator with appropriate pollution control equipment & 10 \\
Thailand's MSWM & Waste-to-Energy system & 1 \\
standards & Mechanical-Biological treatment & 3 \\
& Integrated solid waste management & 12 \\
\hline Non-compliance to & Controlled Dump & 24 \\
Thailand's MSWM & Open dump & 1955 \\
standards & Incinerator with not-up-to-standard pollution control equipment & 45 \\
\hline
\end{tabular}

\subsection{Greenhouse Gas (GHG) Emission and Climate Co-Benefits in MSWM}

Landfilling MSW can worsen climate change mitigation due to GHG generation throughout the process of MSWM. GHG emissions, e.g., $\mathrm{CO}_{2}, \mathrm{CH}_{4}, \mathrm{~N}_{2} \mathrm{O}$, etc., are emitted from anaerobic and aerobic decomposition of organic wastes, i.e., food, leaf, paper, etc. [19]. GHG emissions also come from fossil fuel combustion in the MSW collection and treatment processes [20,21]. Different methods of burying MSW can yield different levels of GHG emissions. Intergovernmental Panel on Climate Change [IPCC] [22] guideline suggests that the methane generating factor is $100 \%$ under deep-depth burying 
schemes (more than $10 \mathrm{~m}$ from surface) and 40\% in shallow-depth burying schemes (less than 5 meter from surface). In general, landfilling of MSW without any pre-treatment or landfill gas recovery emits GHG approximately 1.00-1.70 tons of $\mathrm{CO}_{2}$-eq per ton of waste [23-25]. Flaring methane may not be a complete solution as a significant percentage of fugitive methane is still released $[3,26]$. Method of waste collection and handling of waste also contributes differently to GHG emission rates varying from operations in rural or urban areas [27].

Climate co-benefits from reduction of organic wastes into landfill are recognized mainly through the decrease of methane generation and the methane capture and utilization. Home-composting or biogas generation is the primary alternative for organic waste reutilization [28]. Kurniawan, et al. [29] explored the use of Takakura Home Composting method to manage organic wastes at the household level in Surabaya, Indonesia. The study reported climate co-benefits of 3421 million tons of reduced $\mathrm{CO}_{2}$-eq emission per year. Nevertheless, poorly managed composting and biogas generation may contribute to GHG generation from semi-aerobic or anaerobic conditions [30]. The study found that up to $4 \mathrm{~g}$ of $\mathrm{CH}_{4} / \mathrm{kg}$ of wet waste and $0.3 \mathrm{~g}$ of $\mathrm{N}_{2} \mathrm{O} / \mathrm{kg}$ can be formed in the deep layers of the composting piles. It should be noted that well-managed composting generally offers net avoided GHG emission [22].

For recyclable wastes, various LCA studies demonstrate wide ranges of GHG emissions when raw materials are produced by recycled and virgin materials. For recyclables, climate co-benefits are generated by diverting recyclables from being landfilled and are recycled as raw materials. Eriksson, et al. [31] studied different MSWM scenarios in three Swedish municipalities and found that implementation of material sorting followed by reutilization of energy-rich wastes and recyclable materials is superior to putting all wastes into landfill in terms of GHG emissions. Overall, most separated wastes, i.e., glass, plastic, paper, metals, and aluminum, that enter into the recycling and remanufacturing system yield the least environmental impacts or even create positive outcomes for the environment by helping to reduce environmental impacts and GHG emissions [32,33].

\subsection{Community-Based MSWM}

Community-based management (CBM) is a bottom-up approach to solve problems where members of the community function as core operators. Efficiency comparisons between CBM and traditional models often found that CBM can resolve issues effectively with less burden on other taxpayers [34-36]. Employing CBM as a tool for resource management has been found in the fields of water resource management [37,38], forest management [39,40], community services [41,42], etc.

For solid waste management, CBM activities are employed for both regular MSW services and specific waste services. For regular MSW services, CBM members collect refuses from households, and sort and manage wastes $[43,44]$. Specific waste services focus on certain types of waste, e.g., only accept recyclables for further recycling activities or only organic wastes for composting/biogas generation. In addition to promoting better resource reutilization, associated benefits of CBM in MSW are also reported such as rising incomes for CBM members due to better economy of scale and the reduction of health risks from random scavenging [45]. An example can be found in the city of Surabaya, Indonesia where it successfully manages organic wastes using a community composting system $[29,46]$. Other examples include the recycling program by waste picking service of Zabbaleen group in Cairo, Egypt or CBM projects in Lusaka [44,47]. In Thailand, CBM for MSWM are often chartered as "waste bank programs". 
Program operators act as an intermediary in order to sell sorted recyclables at greater net revenues. Activities are often taken part in as a collaboration between waste generators and other entities that agree to host recyclables at their site (often at schools or community centers). Success of waste bank activities in Thailand has been varied depending on the social structure and political situation $[48,49]$. Examples of community-based MSWM are provided in Table 3.

Table 3. Performance of community-based MSWM.

\begin{tabular}{|c|c|c|}
\hline Activity & Incentive & Reutilization Metric \\
\hline \multicolumn{3}{|c|}{ Regular MSW Collection and Disposal Service } \\
\hline Enugu, Nigeria [50] & Cash revenue higher than minimum wage & $\begin{array}{l}\text { Potential earning of } \\
3.91-5.47 \text { USD per day }\end{array}$ \\
\hline $\begin{array}{l}\text { Guiyang, People Republic of } \\
\text { China [51] }\end{array}$ & Monetary incentive for MSW separation & $87.3 \%$ of MSW is separated \\
\hline Nungankkan, India [52] & De facto rights to provide service & $6.5 \%$ of generated MSW is sold \\
\hline Jubilee Hills, India [52] & De facto rights to provide service & $\begin{array}{c}25 \% \text { of generated MSW, } \\
1 / 2 \text { as compost, and } 1 / 2 \\
\text { as recyclables }\end{array}$ \\
\hline \multicolumn{3}{|c|}{ Waste Bank Operations } \\
\hline Rayong municipality, Thailand [53] & Community recognition and cash return & $17.33 \mathrm{~kg} / \mathrm{member}$ \\
\hline Yala municipality, Thailand [48] & $\begin{array}{l}\text { Bartering between unused recyclables } \\
\text { to egg }\end{array}$ & $15.71 \mathrm{~kg} / \mathrm{member}$ \\
\hline $\begin{array}{l}\text { Averaged } 10 \text { community-based } \\
\text { programs in Thailand [49] }\end{array}$ & Community recognition and cash return & $18.6 \mathrm{~kg} / \mathrm{member}$ \\
\hline $\begin{array}{l}\text { Average } 100 \text { school-based } \\
\text { programs in Thailand [49] }\end{array}$ & Community recognition and cash return & $32.13 \mathrm{~kg} / \mathrm{member}$ \\
\hline
\end{tabular}

This study aimed to quantify and benchmark co-benefits of engaging in CBM of municipal solid waste reutilization with GHG abatement and reduced landfilling costs. Though the boundary of this study is within Thailand, findings from this research may also be applicable to other developing countries that may face a similar waste management situation. The objective of this study is to evaluate co-benefits in terms of GHG reduction and avoided landfill costs from implementation of community-based management (CBM) programs for municipal solid waste (MSW). The study also focused on demonstration mechanism at the local level and community involvement programs with operational waste banks. The efficiency of collecting recycling wastes can be increased. Similar systems can be applied to other communities in other countries.

\subsection{Site Description}

\subsubsection{Targeted Study Site: Thumbon Phang Khon Municipality (PKM)}

Thumbon Phang Khon municipality (PKM), depicted in Figure 1, is a small municipality located in Sakon Nakorn province in the northeastern region of Thailand. The municipality is well recognized for its MSW reutilization activities. 
PKM runs a voluntary MSW collection service that charges members 1.95 USD (Exchange rate: $1 \mathrm{USD}=30.73$ Thai Baht) per household per year to receive waste collection service daily. PKM operates a semi-sanitary landfill with an oxidative pond for leachate treatment. At the time of study, there is no material recovery facility at the landfill but the municipality allows scavenging activities between 8:00 and 14:00 daily. The landfill is also contracted to accept MSW from other municipalities at the rate of 16.27 USD/ton, and 32.54 USD/ton if the MSW comes from a private entity.

PKM also facilitates two voluntary MSW reduction programs to reduce landfilling of MSW including:

- Waste bank program: PKM staffs collect recyclable wastes from 11 villages according to prearranged schedule by visiting two to three villages every Thursday. The municipality acts as a trader by buying recyclables, i.e., plastics, paper, glass, aluminum items, and metals, from waste bank's members and sorts these recyclables to increase the resale value. Finally, the municipality sells sorted materials to a recycling company. Transactions between PKM's waste bank and its members are settled in a credit system. Members and waste bank officers witness the weighting and sign in the transaction recording book. The members can withdraw their balances every Monday of the following week. The program, as an incentive, also provides around 160 USD funeral-assistance benefit to family members of whom pass away if two conditions are met: (1) the member maintains a minimum of 16.27 USD in his/her waste bank account at the time of death and (2) the member sells their recyclables to the waste bank within the last month before his or her death. As of October 2013, there are 522 members actively participating in the program.

- Organic waste reutilization program: PKM provides technical support to its residents by installing waste composting bins and household-scale biogas generating systems at a subsidized cost, and routinely visits the participants. Residuals from biogas generation and compost are used in rice fields and for other agricultural practices in the municipality.

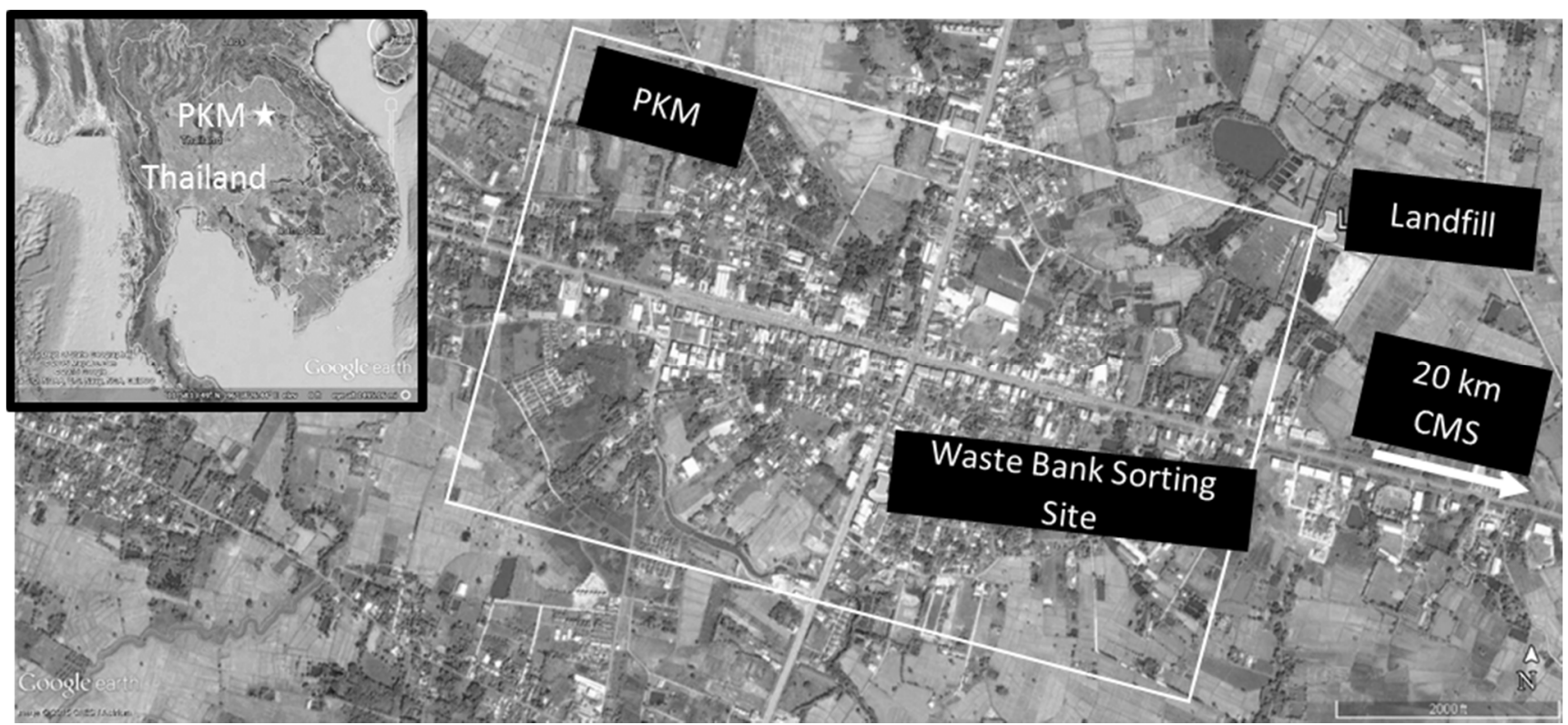

Figure 1. Map of Thumbon Phang Khon Municipality (PKM) (Courtesy of Google). 


\subsubsection{Reference Site: Chang Ming Sub-District Administration Organization (CMS)}

Chang Ming Sub-district Administration Organization (CMS), located within the vicinity of PKM, is an administrative area that is not qualified to be chartered as a municipality, due to its failure to meet the requirements of minimum self-collected tax revenue. The MSW collection service is on a voluntary-basis in which the subscribers pay 1 USD per month for a pickup of each 120-L trash bin on a weekly basis. The residents can also opt to manage MSW themselves. Despite being classified as non-municipality, CMS was selected for comparison with MSW characteristics from PKM because CMS service subscribers are mostly living in an urbanized part of the administrative area. CMS is the only urban settlement within proximity to PKM that does not officially promote any MSW reduction program at the time of this study.

Table 4. Socio-economic background of PKM and CMS.

\begin{tabular}{lcc}
\hline \multicolumn{1}{c}{ Aspects } & $\begin{array}{c}\text { Phang Khon municipality } \\
\text { (PKM) }\end{array}$ & $\begin{array}{c}\text { Chang Ming Sub-district } \\
\text { Administration (CMS) }\end{array}$ \\
\hline Major economic activities & $\begin{array}{c}\text { Retails, government office, } \\
\text { private sector }\end{array}$ & Agricultural \\
\hline Area under management $\left(\mathrm{km}^{2}\right)$ & 3.29 & 51.2 \\
\hline $\begin{array}{l}\text { Percent of household subscribing to } \\
\text { waste collection service }\end{array}$ & $100.00 \%$ & $37.68 \%$ \\
\hline populations receiving MSW service & 6848 & 3478 \\
\hline $\begin{array}{l}\text { Annual generation rate per } \\
\text { registered population }\end{array}$ & $372.30 \mathrm{~kg} /$ capita & $322.15 \mathrm{~kg} / \mathrm{capita}$ \\
\hline Frequency of MSW collection & More frequent than every 3 days & Weekly basis \\
\hline $\begin{array}{l}\text { Government-facilitated MSW } \\
\text { recycling system }\end{array}$ & $\begin{array}{r}\text { Yes-waste bank, composting, } \\
\text { and household biogas }\end{array}$ & No \\
\hline
\end{tabular}

\section{Methodology}

\subsection{Identifying Annual MSW Quantity from Household}

Accurate estimation of at-source MSW generation is crucial for the evaluation of effectiveness in terms of MSW reduction activities. This study attempted to verify performances of MSWM from PKM and CMS. The unit of analysis was set as "an annual MSW generation of the town $\left(\mathrm{W}_{M S W}\right)$ " which is equivalent to

$$
W_{M S W}=\sum W_{L f_{i}}+\sum W_{R e_{i}}+\varepsilon
$$

where $W_{\mathrm{Lf}_{i}}=$ quantity of MSW arrived at the landfill; $W_{\mathrm{Re}_{i}}=$ quantity of reutilized MSW by organic waste reutilization and the waste bank; $\varepsilon=$ quantity of MSW missing from MSWM; $i=$ Waste types, i.e., organic waste, plastic, paper, etc.

The true value of $\varepsilon$, by its nature, is, however, unknown. An approximation of $\varepsilon$ parameter can be estimated by comparing the accounted weight of $\mathrm{MSW}\left(\mathrm{W}_{M S W-b u}\right)$ against that of a top-down approach $\left(\mathrm{W}_{M S W-t d}\right)$ which is calculated by multiplying Thailand's default MSW generation rate per capita to the 
number of populations receiving MSW service (listed in Table 4). The mass balance equation can be expressed as follows:

$$
W_{M S W}=\left(W_{M S W-b u}\right)=\left(W_{M S W-t d}\right)=\sum W_{L f_{i}}+\sum W_{R e_{i}}+\varepsilon
$$

\subsection{Duration of Data Collection for MSW Characterization}

The characterizations of MSW from PKM and CMS were conducted on 28 and 29 October 2013 at the landfill to estimate the percentage of each waste type that arrives at the landfill. MSW was segregated until the volume of MSW was reduced to $200 \mathrm{~L}$. The remaining MSW was then characterized on weight-basis using a scale readable to $0.01 \mathrm{~kg}$ according to the following waste types $(i)$ : organic wastes, plastic, paper, glass, garments, aluminum and miscellaneous wastes. The process was repeated three times for MSW of each town in order to obtain more representative samples. Percentage of waste type $i$ in MSW (\% $\left(\mathrm{Lf}_{i}\right)$ was then multiplied by the mean of MSW arrived at the landfill from September 2012 to September 2013.

The quantity of reutilized MSW through organic waste reutilization was reported by municipality staff who conducted regular site visits. The quantity of recyclables arriving in the waste bank, $\operatorname{Re}_{i}$, was calculated based on receipts from selling recyclables to recycling shops during September 2012 to September 2013. It should be noted that the weight recorded in the receipts was matched to the record of recyclable waste taken from the members.

\subsection{Quantification of Co-Benefits}

GHG Emissions and Climate Co-Benefit

Assessment of GHG emission was conducted using the annual MSW generation quantity ( $\left.\mathrm{W}_{M S W}\right)$ of each studied waste type .This study followed methodology used under Tier-1 guideline [22]. All emission factors used in this study were based on the conversion of emitted GHG into the unit of ton $\mathrm{CO}_{2}$ equivalent (GWP 100-years). Emission factors for landfilling MSW from organic waste decomposition waste obtained from Athitanun [54] while co-benefit from organic waste reutilizations (composting and biogas generation) were obtained from IPCC [22]. Climate co-benefit (Avoided GHG emission) was calculated based on the amount of raw material that was recycled, and the GHG emission savings, compared to emissions from the manufacturing of raw materials from the virgin source, as obtained from IPCC [22] and Browne, et al. [55], listed in Tables A1 and A2.

GHG emission factors in transportation, Listed in Table A3, and landfilling phases, listed in Table A4, were taken from Thailand Greenhouse Gas Management Organization [TGO] [56]. For transportation, we assumed that travel distance of garbage trucks was based on the weight-km format and the collection fleet was assumed to operate at $50 \%$ of their full capacity.

The generic GHG equation can be expressed as follow with explanations given in Table 5:

$$
G H G=\text { weight of waste } \times \text { emission factor }
$$

And,

$$
G H G_{G t}=\sum G H G_{o r}-\sum G H G_{R e}+\sum G H G_{C o \_r g}+\sum G H G_{C o_{-} w b}+\sum G H G_{L f_{-} o p}
$$


Table 5. Mathematical formula to quantify GHG emissions.

\begin{tabular}{|c|c|c|}
\hline $\mathrm{GHG}_{G t}$ & $=$ & net GHG emssion \\
\hline$\sum \mathrm{GHG}_{\mathrm{or}}$ & $=$ & sum of GHG emission from MSW decomposition \\
\hline $\mathrm{GHG}_{\mathrm{Re}}$ & $=$ & $\begin{array}{l}\text { sum of avoided GHG emission activities, including organic waste } \\
\text { reutilization and using raw materials produced from recycled sources } \\
\text { instead of virgin source }\end{array}$ \\
\hline$\sum \mathrm{GHG}_{\mathrm{Co}_{-} \mathrm{rg}}$ & $=$ & $\begin{array}{l}\text { sum of GHG emission from regular MSW collection services minus } \\
\text { avoided GHG emission from collection service under different scenarios }\end{array}$ \\
\hline$\sum \mathrm{GHG}_{\mathrm{Co}_{-} w b}$ & $=$ & sum of GHG emission from the waste bank collection services \\
\hline$\sum \mathrm{GHG}_{\mathrm{Lf} \_\mathrm{op}}$ & $=$ & $\begin{array}{l}\text { sum of GHG from landfilling process minus avoided GHG emission from } \\
\text { diversion of MSW from landfill under different scenarios }\end{array}$ \\
\hline
\end{tabular}

\subsection{Scenario Development}

To estimate potential reduction of GHG emissions and cost of landfilling under changes in MSWM practices, four scenarios were developed to illustrate net benefits. (See Figure 2):
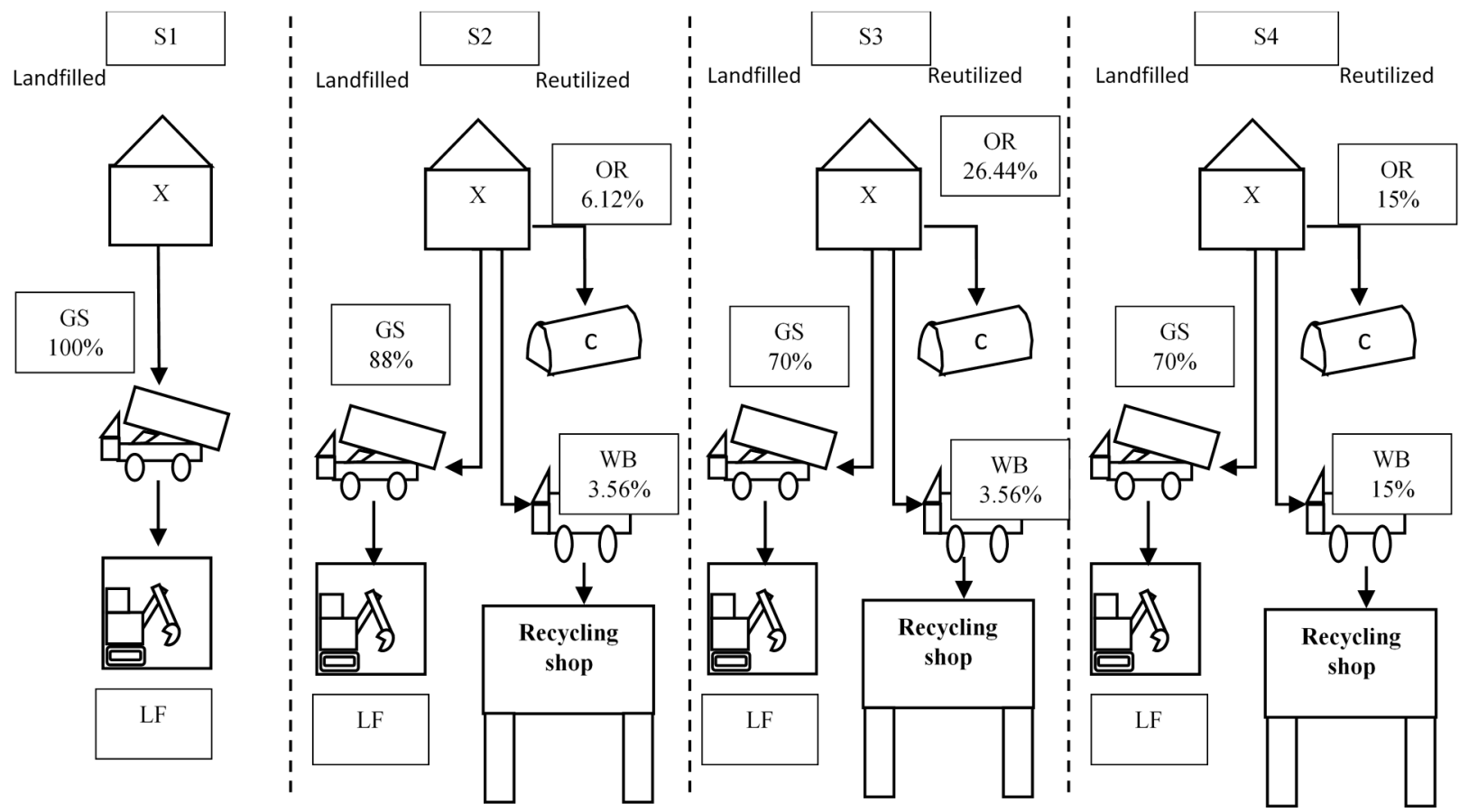

Figure 2. Flows of MSW under different scenarios. $X$ — annual MSW generated from PKM; $\mathrm{C}$-Compost and Biogas; GS - General MSW collection service; OR-Organic waste reutilization $\mathrm{s}$, and $\mathrm{WB}$-Waste bank.

(1) $\mathrm{S}_{1}$ - Baseline scenario. In this scenario, most of the generated MSW is assumed to be landfilled.

(2) $\mathrm{S}_{2}$ - Current MSW utilization scenario. This scenario describes the current MSW situation with $3.56 \%$ of generated MSW diverted by the waste bank and $6.12 \%$ of generated MSW diverted by organic reutilization (assumed 50\% composting and 50\% biogas generation).

(3) $\mathrm{S}_{3}$ - This scenario assumes that a $30 \%$ reutilization rate, the national MSW reutilization target of Thailand, is achieved by boosting the organic waste reutilization solely. In this scenario, organic 
waste reutilization is assumed to increase to $26.44 \%$ of generated MSW while the rate of generated MSW diverted by the waste bank remains at 3.56\%.

(4) $\mathrm{S}_{4}$ - This scenario assumes that a $30 \%$ reutilization rate, the national MSW reutilization target of Thailand, is achieved by splitting the $30 \%$ quota equally between diverted organic reutilization and diverted recyclables through the waste bank (assuming an additional contribution to meet the waste bank's $15 \%$ quota is made by increasing only the share of recycled plastics while other recycled wastes remain at the same percentage of $S_{2}$ ).

\section{Result and Discussion}

\subsection{Situation of MSWM in PKM and CMS}

\subsubsection{Mass Accounting}

Based on mass accounting, the accounted weight of MSW $\left(\mathrm{W}_{M S W-b u-P K M}\right)$ is at 2534 tons per annum. This MSW arriving at the landfill $\left(\sum W_{\mathrm{Lf}_{i}}=2288\right.$ tons per annum) and reutilized wastes in producing compost, bio-gas generation, and recycling by the waste bank ( $\sum W_{R e_{i}}=246$ tons per annum). The result from the generated MSW $\left(\mathrm{W}_{M S W-t d-P K M}\right)$ calculation of the top-down approach indicated that MSW was generated at the rate of 2549 tons per annum.

From Equation (2), the missing quantity of MSW from MSWM system $\left(\varepsilon_{P K M}\right)$, derived from the difference between $\mathrm{W}_{M S W-b u-P K M}$ and $\mathrm{W}_{M S W-t d-P K M}$, was estimated to be 14 tons or $0.59 \%$, which is slightly lower than $\mathrm{W}_{M S W-t d-P K M}$ and assumed to be negligible since loss of MSW may occur during operation or through loss of moisture. Hence, the value of the unit of analysis was set based on the top-down approach as the at-source generated MSW. For PKM, the unit of analysis $\left(\mathrm{W}_{M S W_{p k m}}\right)$ is 2549 tons per year. For CMS, the unit of analysis for at-source generated MSW(W MSW_CMS $\left._{2}\right)$ was set based on the calculation of the top-down approach $\left(\mathrm{W}_{M S W-t d-C M S}\right)$ which is 1155 tons per year.

From Figure 3, mass flow of MSW from PKM's households to disposal points, landfill, composting points, or the waste bank indicated that MSWM of PKM was very effective because only $0.50 \%$ of MSW was not accounted for in the system based on comparison of $\mathrm{W}_{M S W-b u-P K M}$ and $\mathrm{W}_{M S W-t d-P K M}$. PCD [12] reported that $25.16 \%$ of generated MSW had disappeared before it was collected for further treatment. In contrast, $35.08 \%$ of generated MSW from CMS was not accounted for when MSW from CMS arrived at the landfill (mass flow of CMS based on the top town approach compared to the bottom up approach).The cause of missing wastes may come from an inefficient collection service or some recyclables is removed prior to the arrival at the landfill.

\subsubsection{MSW Characteristics and Changes from Reutilization Activities}

We found that MSW characteristics of PKM and CMS were consistent with Thailand's national average of waste composition for small towns in developing countries in South East Asia [57-59]. Impacts of the waste bank were observed in the reduction of recyclables at the landfill due to waste bank activities. From MSW characterization, recyclable components from PKM were consistently lower than those of CMS despite the fact that PKM is a more urbanized town and therefore should have higher recyclable content compared to that of CMS. Only recyclables that were not accepted by the waste bank, 
i.e., green glass bottles or food-contaminated plastic waste, were found in PKM's MSW. Overall, recyclables from PKM were found to be $4.34 \%$ of MSW arriving at the landfill in contrast to $15.35 \%$ of those from CMS.

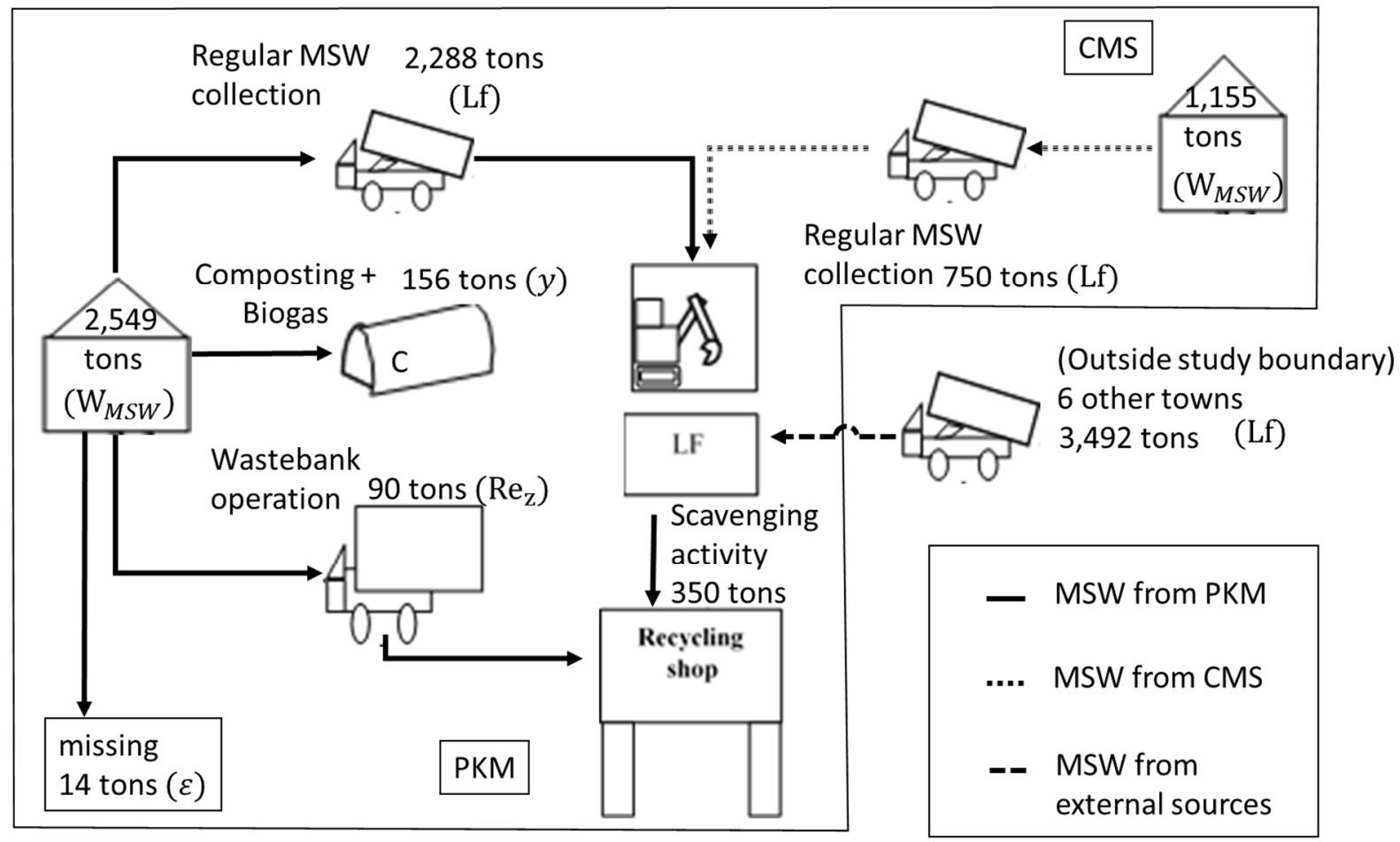

Figure 3. Annual flow of MSW arriving at PKM's landfill.

Table 6 suggested that organic waste was the highest waste type, followed by plastic and paper wastes. The percentages and trends of MSW composition, however, were found to change significantly in the last decade for both CMS and PKM. This was true for the composition of organic waste, paper waste, and plastic waste types. The percentage drop of food waste composition can be potentially explained by an increase of affordability for refrigerators as observed by Hoornweg and Bhada-Tata [8]. Plastic waste - mainly dirty or contaminated plastic bags — was, however, found to have an increasing trend.

Table 6. Characteristics of MSW from towns within PKM vicinity.

\begin{tabular}{cccccc}
\hline \multirow{2}{*}{ Composition } & \multicolumn{2}{c}{$\mathbf{2 0 0 4 - 2 0 0 6}$} & \multicolumn{3}{c}{$\mathbf{2 0 1 3}$} \\
\cline { 2 - 6 } & $\begin{array}{c}\text { Averaged in the } \\
\text { region [57] }\end{array}$ & PKM [60] & $\begin{array}{c}\text { CMS at sources } \\
\left(\% \boldsymbol{W}_{\mathbf{a g}_{i}}\right)\end{array}$ & $\begin{array}{c}\text { PKM at sources } \\
\left(\% \boldsymbol{W}_{\mathbf{a g}_{i}}\right)\end{array}$ & $\begin{array}{c}\text { PKM at landfill } \\
\left(\boldsymbol{W}_{\mathbf{L f}}\right)\end{array}$ \\
\hline Organic & $64.36 \%$ & $67.82 \%$ & $45.90 \%$ & $56.70 \%$ & $56.30 \%$ \\
Paper & $7.58 \%$ & $5.66 \%$ & $4.60 \%$ & $3.60 \%$ & $2.70 \%$ \\
Glass & $3.30 \%$ & $2.12 \%$ & $6.30 \%$ & $3.90 \%$ & $1.60 \%$ \\
Plastics & $17.26 \%$ & $17.88 \%$ & $33.40 \%$ & $31.40 \%$ & $34.60 \%$ \\
Garment & $1.18 \%$ & $2.04 \%$ & $8.10 \%$ & $2.50 \%$ & $2.80 \%$ \\
Aluminum & $0.97 \%$ & $0.72 \%$ & $0.40 \%$ & $0.10 \%$ & $0.10 \%$ \\
Metal & $0.97 \%$ & $0.72 \%$ & $0.40 \%$ & $0.20 \%$ & $0.10 \%$ \\
Miscellaneous & $2.69 \%$ & $3.04 \%$ & $1.00 \%$ & $1.60 \%$ & $1.80 \%$ \\
\hline
\end{tabular}




\subsubsection{Efficiency of the Organic Waste Reutilization and Waste Bank Activities}

The organic waste reutilization and waste bank programs in PKM helped reduce landfilling of MSW. Separation of organic wastes also helps prevent undue quality deterioration of recyclables. This has been done through a monetary incentive scheme, which entailed a wide range of price differences between unsorted and sorted waste, e.g., 16.66\% higher price for newspapers in good condition and 18.75\% higher price for clear glass as compared to mixed glass waste. Additional revenues as well as potential budgetary saving from engaging in MSW reutilization can also help increase co-operation within city administrative councils.

It should be noted that the efficiency of MSW reutilization in PKM was not equally distributed across all waste types. Easily recycled waste-types such as paper, glass, aluminum, and metal were recovered at a higher rate compared to organic or plastic waste, which were often contaminated. The quantity of recyclables sold per member, as shown in Table 7, suggested that glass waste, paper, and plastic were among the most common materials in the recyclable stream.

Contrasting to a traditional belief that higher income level tends to correlate with lower level of participation in MSW recycling [61], the results from Table 7 suggested that the waste bank members living in the more affluent area, i.e., Route $\mathrm{D}$, sent more recyclables to the waste bank than the members in the less affluent areas, namely Route A to C.

Table 7. Average annual recycling rates of waste bank operations per recycler between November 2011 and October 2013.

\begin{tabular}{cccccccc}
\hline $\begin{array}{c}\text { Collection Routes } \\
\text { for Waste Bank }\end{array}$ & $\begin{array}{c}\text { Number of } \\
\text { Members }\end{array}$ & Plastic & Aluminum & Metals & Glass & Paper & Total (kg) \\
\hline Route A & 155 & $10.60 \%$ & $0.48 \%$ & $3.88 \%$ & $55.05 \%$ & $29.99 \%$ & 159.18 \\
Route B & 127 & $11.79 \%$ & $0.42 \%$ & $5.45 \%$ & $61.35 \%$ & $20.99 \%$ & 177.11 \\
Route C & 101 & $12.26 \%$ & $0.59 \%$ & $2.26 \%$ & $54.52 \%$ & $30.37 \%$ & 144.47 \\
Route D & 139 & $6.99 \%$ & $0.56 \%$ & $2.76 \%$ & $60.96 \%$ & $28.74 \%$ & 208.03 \\
Average & 522 & $10.16 \%$ & $0.51 \%$ & $3.61 \%$ & $58.34 \%$ & $27.38 \%$ & 172.20 \\
\hline
\end{tabular}

The success of PKM's waste bank program could also be attributed to the integration of a social dimension into creating incentives for reutilization by providing strong support from the authorities and through the involvement of waste bank members as evidenced by its high recycling performance. The recycling per member of PKM's waste bank was found to be very efficient in terms of $\mathrm{kg}$ of recyclable per member (shown in Table 7) compared to average community-based management activities (18.6 kg of recyclables per member) [53]. Puangsiri [62] conducted separate research on members of the PKM's waste bank and reported that members decide to participate in the waste bank because of the convenience of the curbside pickup service, funeral-assistance benefits, and recycling education from the municipality. The positive development of PKM's CBM can be attributed to PKM's curbside pickup service and recycling awareness, which other waste banks fail to offer. Findings from Puangsiri [62] were consistent with success factors found in other CBM activities in terms of strong public participation, peer support, convenience, and economic incentives as potential factors to sustain environmental-friendly service programs $[63,64]$. 


\subsection{Climate Co-Benefits Analysis}

\subsubsection{Baseline GHG Emission}

Under the baseline scenario (i.e., no implementation of any MSW reutilization activities $\left(\mathrm{S}_{1}\right)$ ), all generated MSW were assumed to be collected and sent to the landfill. The net annual GHG emission $\left(\mathrm{GHG}_{G t}\right)$ from PKM was equal to 1248.57 tons of $\mathrm{CO}_{2}$-eq. Hotspots were identified of organic waste decomposition $\left(\mathrm{GHG}_{O r}=1208.96\right.$ tons of $\mathrm{CO}_{2}$-eq), contributing $96.83 \%$ of total $\mathrm{GHG}_{G t}$. For transportation service, the averaged odometer readout from collection fleets indicated that the fleet runs approximately $79 \mathrm{~km}$ per day. In this scenario, GHG from the collection service $\left(\mathrm{GHG}_{\mathrm{Co}}=21.76\right.$ tons of $\mathrm{CO}_{2}$-eq), contributed to $1.74 \%$ of $\mathrm{GHG}_{G t}$. GHG from landfill operation $\left(\mathrm{GHG}_{\mathrm{Lf}_{-} \text {op }}=17.85\right.$ tons of $\mathrm{CO}_{2}$-eq), contributed to $1.43 \%$ of $\mathrm{GHG}_{G t}$, which mainly came from fuel uses for equipment operation. There was no climate co-benefit occurring in this scenario due to the assumption of no MSW reutilization and exclusion of scavenging activates in the landfill.

From Figure 4, baseline carbon intensity of GHG emissions $(\mathrm{CI})$ was 0.47 tons of $\mathrm{CO}_{2}$-eq per ton of collected MSW. When PKM's CI was compared against CI from other towns, we found that PKM's CI was lower than CIs from other towns with similar size, i.e., 0.67 tons of $\mathrm{CO}_{2}$-eq per ton of collected MSW in Muang Klang municipality [65] or 0.73 tons of $\mathrm{CO}_{2}$-eq per ton of collected wastes in Nonthaburi landfill [66]. A logical explanation could be derived from the simplicity of PKM's MSW collection system as well as low commuting distance between the town and the landfill.

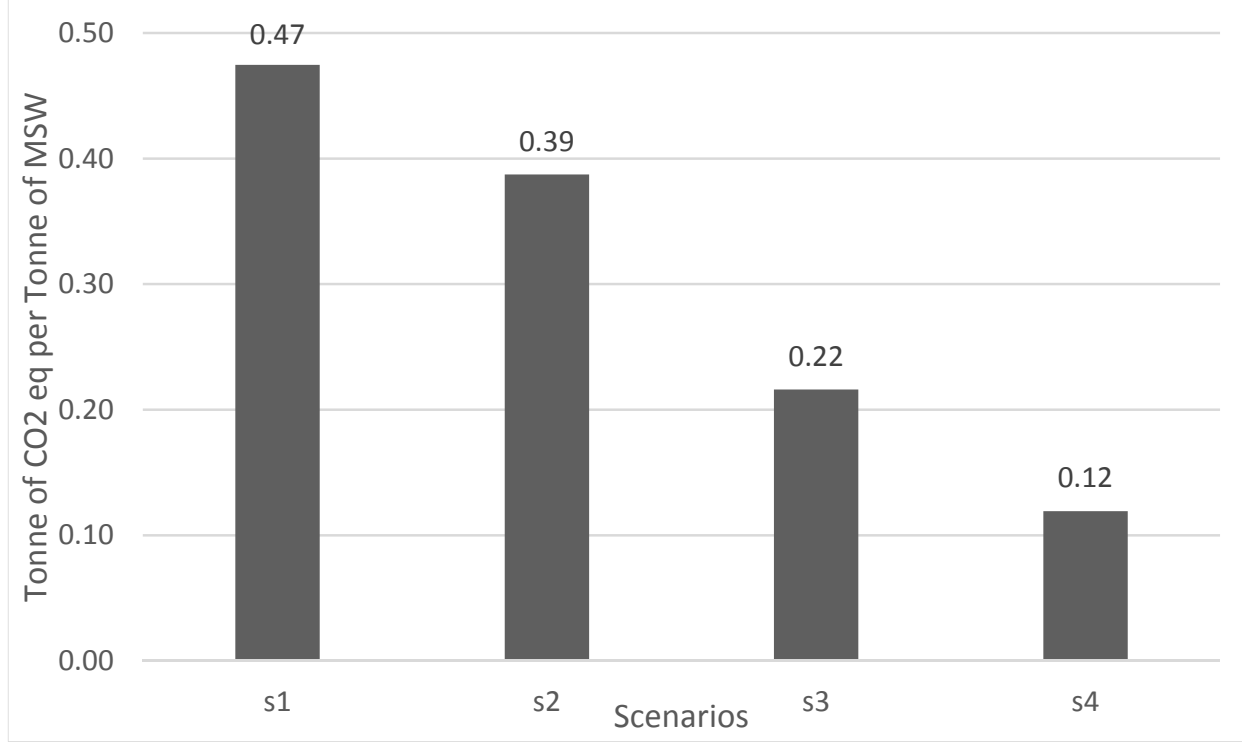

Figure 4. Carbon intensity of MSW decomposition with avoided GHG emission on the MSW.

\subsubsection{Current GHG Emission and Climate Co-Benefits}

Under the current MSW reutilization practice, net $\mathrm{GHG}$ emission $\left(\mathrm{GHG}_{G t}\right)$ was reduced to 1040.04 tons of $\mathrm{CO}_{2}$-eq $\left(16.80 \%\right.$ reduction as compared to $\left.\mathrm{S}_{1}-\mathrm{GHG}_{G t}\right)$. CI in this scenario was reported at 0.39 tons of $\mathrm{CO}_{2}$-eq per ton of MSW. The primary sources of reduction in GHG emission were from MSW reutilization activities where organic waste reutilization through composting and biogas 
generation $\left(\mathrm{GHG}_{R e_{-} \text {Or }}\right)$ was responsible for a $9.67 \%$ reduction of $\mathrm{S}_{1}-\mathrm{GHG}_{G t}$. GHG saving from the waste bank operation $\left(\mathrm{GHG}_{R e_{-} W b}\right)$, by replacing virgin materials, equaled to $7.31 \%$ reduction in $\mathrm{S}_{2}-\mathrm{GHG}_{G t}$ as compared to $\mathrm{S}_{1}-\mathrm{GHG}_{G t}$. Based on the current recycling rate of the waste bank, recycling of paper and glass wastes led to the largest reductions in GHG emissions due to their large quantities as well as the large difference between GHG emissions produced from raw materials and that from virgin and recycled sources.

Net $\mathrm{GHG}$ emission from transportation $\left(\mathrm{GHG}_{\mathrm{Co}}=22.83\right.$ tons of $\mathrm{CO}_{2}$-eq $)$ in this scenario was higher than the GHG emission from the transportation phase in the baseline scenario. Therefore, climate co-benefit from transportation was not recognized in this scenario. The cause of increased GHG emission was from additional vehicle use in the waste bank operation, which was an additional $40 \mathrm{~km}$ drive on a weekly basis. Nevertheless, net GHG emission within the disposal phase was reduced to $\left(\mathrm{GHG}_{\mathrm{Lf} \_\mathrm{op}}=16.01\right.$ tons of $\mathrm{CO}_{2}$-eq $)$ as reutilized wastes were diverted from the landfill.

\subsubsection{Potential Reduction of GHG Emission and Co-benefits}

Under the hypothetical situations where $30 \% \mathrm{MSW}$ reutilization rate were achieved $\left(S_{3}\right.$ and $\left.S_{4}\right)$, the benefits of recycling were pronounced because they were able to reduce GHG emission significantly.

In the $S_{3}$ scenario, the net $\mathrm{GHG}$ emission $\left(\mathrm{GHG}_{G t}\right)$ have been reduced to 650.49 tons of $\mathrm{CO}_{2}$-eq ( $47.60 \%$ reduction from $\mathrm{S}_{1}-\mathrm{GHG}_{G t}$ ) and $\mathrm{CI}$ in this scenario was found at 0.22 tons of $\mathrm{CO}_{2}$-eq per ton of MSW. Primary contributor of the avoided GHG emission could be attributed to the reutilization of organic wastes (avoided 482.78 tons of $\mathrm{CO}_{2 \text {-eq }}$ compared to the baseline scenario) while the contribution of the waste bank remained at the same level of $S_{2}-\mathrm{GHG}_{\mathrm{Re}}$. In the collection and landfilling phases, $\mathrm{GHG}_{\mathrm{Co}}$ in this scenario was at 17.87 tons of $\mathrm{CO}_{2}$-eq $\left(17.88 \%\right.$ lower than that of $\left.S_{1}-\mathrm{GHG}_{\mathrm{Co}}\right)$ due to the reduction of collected MSW to the system. The advantage of prioritizing organic waste reutilization was that the reutilized wastes were not entering into the collection service. This helped lower GHG emission. Avoided GHG emission from landfill operation under this scenario was also reduced by $30 \%$ as compared to that of $S_{1}-\mathrm{GHG}_{\mathrm{Lf} \text { op }}$.

In the $S_{4}$ scenario, the net GHG emission has been reduced to 386.56 tons of $\mathrm{CO}_{2}$-eq $(69.04 \%$ reduction of $\mathrm{S}_{1}-\mathrm{GHG}_{G t}$ ) and $\mathrm{CI}$ in this scenario was found to be at 0.12 tons of $\mathrm{CO}_{2}$-eq per ton of MSW. By boosting organic waste reutilization rate to $15 \%$, avoided GHG emission was attributed to the reutilization of organic wastes (avoided 280.17 tons of $\mathrm{CO}_{2}$-eq compared to GHG emission from landfilling organic waste). For the $15 \%$ quota of boosting the reutilization rate in the waste bank, we set the scenario in the way that we held the reutilization rates of all recyclables, except the rate of plastic waste that was expected to raise to meet the $15 \%$ quota, at the rates found in the $S_{2}$. We rationalized this assumption based on the abundance of plastic waste at the landfill (see Table 6). The result indicated that avoided GHG emissions from the waste bank in this scenario was increased to 584.37 tons of $\mathrm{CO}_{2}$-eq. Puangsiri's study [62] on the attitude toward enhancing PKM's waste bank also pointed out that PKM waste bank's members realized the potential of boosting plastic waste recycling. For collection and landfilling phases, $\mathrm{GHG}_{\mathrm{Co}}$ in this scenario was $1.24 \%$ lower than that of $S_{1}-\mathrm{GHG}_{\mathrm{Co}}$ due to the increase in the waste bank's operation. Avoided GHG emissions from landfill operations under this scenario were reduced by $30 \%$ as compared to that of $S_{1}-\mathrm{GHG}_{\mathrm{Lf} \_ \text {op }}$. 


\subsection{Co-Benefits for Saving of MSW Services}

Data from the feasibility study report for the construction of the PKM's landfill reported that estimated cost for landfilling 1 ton of MSW is approximately 7.41 USD (adjusted to USD's 2013 value). However, if landfill space can be used efficiently for non-recyclable waste instead of all wastes, the municipality can receive additional profits from accepting the MSW service fee from other municipalities (expected profit at 8.86 USD of every ton of accepted MSW). Under the baseline scenario, we assumed that generated MSW from PKM $\left(\mathrm{W}_{M S W_{-} p k m}=2549\right.$ tons per year $)$, we calculated that PKM would spend 18,884 USD annually for landfilling MSW and that also the loss opportunity would accrue to 22,584 USD from service landfill space to other municipalities. Within the current scenario $\left(\mathrm{S}_{2}\right)$, we expected that PKM were able to save 2181 USD and reduce the landfill cost to 6.55 USD per ton of generated MSW. In the scenarios where the reutilization rates attained the $30 \%$ reutilization target $\left(\mathrm{S}_{3}-\mathrm{S}_{4}\right)$, we estimated that the financial co-benefit could reach 6777.13 USD per year, reducing the landfill cost to 4.75 USD per ton of generated MSW.

\section{Conclusions}

This study provides some important lessons. CBM activities have been proved to provide the co-benefit of a reduction of financial burden for administration and operation from the minimization of landfill for MSW and the generation of income from sales of recyclables from CBM members. Another benefit from CBM is the lowering of GHG emissions in non-landfilling scenarios compared to the completely landfilled scenario. Findings from the study suggested that key success factors may stem from the synergism between curbside recycling services, community-wide collaboration, understanding of benefits from recycling, and fair pricing of recyclables purchased at the waste bank, which help to sustain participation in CBM activities.

Key findings derived from the case studies suggested that MSW reduction through CBM activities can potentially be extended and implemented in up to around $50 \%$ of residential communities in Thailand and South East Asia, where populations still reside in rural/peri-urban settlements [67]. Organic waste reutilization programs e.g., composts and residual from biogas generation, are highly applicable to the agricultural-based society and peri-urban/rural settlements as the majority of MSW characteristics are organic-based waste types [8]. When settlements become more urbanized, the demand for home composting or biogas generation may diminish due to changes in lifestyle and economic activities. The importance of waste bank functions of a CBM program may be higher due to higher recyclable contents in the waste stream. For organic wastes, it is likely that a more advanced model of MSW recycling may be more suitable, i.e., refuse-derived fuel produced by mixture of plastic, garden, and paper wastes, or large-scale anaerobic digestion system for food and organic wastes.

Although widely used MSWM methods i.e., landfill or open dumping, may have relatively lower initial investment costs, in the long run these methods can incur expensive operating costs as well as produce significant adverse impacts on the environment, particularly climate change. Therefore, the association of climate co-benefits and the ability to save public funds through MSW reutilization should be promoted widely, in order to raise public awareness, provide clear benefits, and create incentives for comprehensive waste management for citizens nationwide. 


\section{Acknowledgments}

This research received financial support from Center of Excellence on Hazardous Substance Management (HSM) Chulalongkorn University and the 90th Anniversary of Chulalongkorn University Fund (Ratchadaphiseksomphot Endowment Fund). The authors would like to thank the Mayor, Municipality Clerk, Director of Public Health Division, and staff members of PKM, Kraisri Srithupthai from Rajamangala University of Technology Isan Sakonnakhon campus for their helps and assistances during and after my filed study and data collection in Phang Khon municipality. The authors would like to specially thank Krip Rojanastien and Chiva-Som International Health Resort for the generous support in research activities, and Tatthap Veeratat for his help during landfill visits and data collection, Attasit Korchaiyapruk for his valuable comments and suggestions.

\section{Author Contributions}

Chanathip Pharino and Amornchai Challcharoenwattana conceived and designed the research; Amornchai Challcharoenwattana performed the data collection and analyzed the data. Chanathip Pharino supervised data collection and verified the analysis and results. Amornchai Challcharoenwattana drafted the manuscript and Chanathip Pharino substantially reviewed, commented, and edited the manuscript.

\section{Conflicts of Interest}

The authors declare no conflict of interest.

\section{Appendix}

Table A1. Emission factors for conventional MSW disposal activities.

\begin{tabular}{|c|c|c|c|}
\hline \multirow{2}{*}{ practices } & \multicolumn{2}{|c|}{ Emission Factors (tons of $\mathrm{CO}_{2}$-eq per ton waste type) } & \multirow{2}{*}{ Source } \\
\hline & Baseline practice $\left(\mathrm{Ef}_{\mathrm{Lf}}\right)$ & Alternatives $\left(\mathrm{Ef}_{\mathrm{Or}_{\mathrm{v}}}\right)$ & \\
\hline Buried MSW in shallow landfill & $8.42 \times 10^{-1}$ & - & \\
\hline Biogas generation & - & $4.20 \times 10^{-2}$ & IPCC [22] \\
\hline Composting & - & $1.77 \times 10^{-1}$ & IPCC [22] \\
\hline
\end{tabular}

Table A2. Emission factors for recycling activities.

\begin{tabular}{|c|c|c|c|}
\hline \multirow{2}{*}{ Practices } & \multicolumn{2}{|c|}{ Emission Factors (tons of $\mathrm{CO}_{2}$-eq per ton of waste type) } & \multirow{2}{*}{ Source } \\
\hline & Virgin material $\left(\mathbf{E f}_{\mathbf{v i r}_{\mathrm{Z}}}\right)$ & Recycled material $\left(\mathrm{Ef}_{\mathrm{re}_{\mathbf{z}}}\right)$ & \\
\hline Glass & 1.03 & $3.30 \times 10^{-1}$ & Browne, O’Regan and Moles [55] \\
\hline Paper & 2.86 & 1.58 & Browne, O'Regan and Moles [55] \\
\hline Plastic & 3.74 & 2.05 & Browne, O'Regan and Moles [55] \\
\hline Ferrous & 2.49 & 1.28 & Browne, O’Regan and Moles [55] \\
\hline Aluminum & 8.80 & 2.16 & Browne, O’Regan and Moles [55] \\
\hline
\end{tabular}


Table A3. Emission factors from collection services (emission factor of diesel).

\begin{tabular}{|c|c|c|c|c|c|c|}
\hline Vehicle \# (x) & $\begin{array}{c}\text { Type of } \\
\text { Collection } \\
\text { Truck } \\
\end{array}$ & $\begin{array}{c}\text { Fuel } \\
\text { Economy } \\
(\mathrm{Km} / \mathrm{L}) \\
\end{array}$ & $\begin{array}{c}\mathbf{k m} \\
\text { Travel }\end{array}$ & $\begin{array}{c}\text { MSW } \\
\text { Collected } \\
\text { (Tons) } \\
\end{array}$ & $\begin{array}{c}\text { Rate of Fuel } \\
\text { Consumption } \\
\text { (L/tons MSW) } \\
\end{array}$ & $\begin{array}{l}\text { Emission Factor (tons } \\
\text { of } \mathrm{CO}_{2} \text {-eq/tons } \mathrm{MSW} \times \\
\text { distance }(\mathbf{k m}))\left(\mathbf{E f}_{\mathrm{Vh}_{\mathrm{x}}}\right)\end{array}$ \\
\hline \multicolumn{7}{|c|}{ Regular garbage collection } \\
\hline 1 & 4-wheel trucks & 3.50 & $8.98 \times 10^{3}$ & $5.26 \times 10^{3}$ & 4.88 & $1.47 \times 10^{-6}$ \\
\hline 2 & $\begin{array}{l}\text { 4-wheel trucks } \\
\text { with compactor }\end{array}$ & 4.00 & $6.42 \times 10^{3}$ & $5.26 \times 10^{3}$ & 3.06 & $1.29 \times 10^{-6}$ \\
\hline 3 & $\begin{array}{l}\text { 6-wheel truck } \\
\text { with compactor }\end{array}$ & 4.00 & $7.88 \times 10^{3}$ & $8.76 \times 10^{2}$ & 2.25 & $7.73 \times 10^{-7}$ \\
\hline 4 & 4-wheel truck & 6.00 & $7.88 \times 10^{3}$ & $3.50 \times 10^{2}$ & 3.75 & $1.29 \times 10^{-6}$ \\
\hline \multicolumn{7}{|c|}{ Waste bank Operation } \\
\hline 1 & 4-wheel trucks & 3.50 & $5.16 \times 10^{2}$ & 52.9 & 11.7 & $1.46 \times 10^{-5}$ \\
\hline 2 & 4-wheel trucks & 3.50 & $5.16 \times 10^{2}$ & 52.9 & 11.7 & $1.46 \times 10^{-5}$ \\
\hline
\end{tabular}

Table A4. Emission factors for landfilling process.

\begin{tabular}{|c|c|c|c|}
\hline Operation & Unit/year & $\begin{array}{c}\text { Annual MSW arrived at landfill } \\
\text { (tons) }\end{array}$ & $\begin{array}{c}\text { Calculated EF } \\
\left.\text { (tons of } \mathrm{CO}_{2} \text {-eq/tons } \mathrm{MSW}\right)\left(\mathrm{Ef}_{\mathrm{eq}_{\mathrm{i}}}\right)\end{array}$ \\
\hline $\begin{array}{l}\text { Excavator \& Tractor } \\
\text { ( } \mathrm{L} \text { of diesel })\end{array}$ & $5.06 \times 10^{3}$ & $2.28 \times 10^{3}$ & $6.01 \times 10^{-3}$ \\
\hline Electricity (kWh) & $3.99 \times 10^{3}$ & $2.28 \times 10^{3}$ & $9.83 \times 10^{-4}$ \\
\hline \multicolumn{3}{|c|}{ total } & $7.00 \times 10^{-3}$ \\
\hline
\end{tabular}

\section{References}

1. Gentil, E.; Christensen, T.H.; Aoustin, E. Greenhouse gas accounting and waste management. Waste Manag. Res. 2009, 27, 696-706.

2. Aguilar-Virgen, Q.; Taboada-González, P.; Ojeda-Benítez, S. Analysis of the feasibility of the recovery of landfill gas: A case study of Mexico. J. Clean. Product. 2014, 79, 53-60.

3. Menikpura, S.; Sang-Arun, J.; Bengtsson, M. Climate co-benefits of energy recovery from landfill gas in developing Asian cities: A case study in Bangkok. Waste Manag. Res. 2013, 31, 1002-1011.

4. Zaman, N.Q.; Jam, Z.M. Odour Nuisance and the Need for Effective Complaint Measures in Malaysia: A Case Study of a Public Institution in Penang. Chem. Eng. 2014, doi:10.3303/CET1440017.

5. Owusu, G.; Nketiah-Amponsah, E.; Codjoe, S.N.A.; Afutu-Kotey, R.L. How do Ghana's landfills affect residential property values? A case study of two sites in Accra. Urban Geogr. 2014, 35, $1140-1155$.

6. Hite, D.; Chern, W.; Hitzhusen, F.; Randall, A. Property-Value Impacts of an Environmental Disamenity: The Case of Landfills. J. Real Estate Finance Econ. 2001, 22, 185-202.

7. Un-Habitat. Solid Waste Management in the World's Cities Water and Sanitation in the World's Cities 2010; Un-Habitat: London, UK; Washington, DC, USA, 2010.

8. Hoornweg, D.; Bhada-Tata, P. What a Waste: A Global Review of Solid Waste Management; The Worldbank: Washington, DC, USA, 2012. 
9. Mazzanti, M.; Montini, A.; Zoboli, R. Municipal Waste Generation and Socioeconomic Drivers: Evidence from Comparing Northern and Southern Italy. J. Environ. Dev. 2008, 17, 51-69.

10. Nestor, D.V. Policy Evaluation with Combined Actual and Contingent Response Data. Am. J. Agric. Econ. 1998, 80, 264-276.

11. Taylor, D.C. Policy incentives to minimize generation of municipal solid waste. Waste Manag. Res. 2000, 18, 406-419.

12. PCD. Thailand State of Pollution Report B.E. 2555 (2012); Thailand's Pollution Control Department: Bangkok, Thailand, 2013.

13. Bangkok Metropolitan Administration. Bangkok State of the Environment 2012; Rong Pim Auk Sorn Thai, LP: Bangkok, Thailand, 2013.

14. JICA (Japan International Cooperation Agency). Project on the Strengthening of Solid Waste Management for the Municipality of Phnom Penh; JICA: Phnom Penh, Cambodia, 2008.

15. Seng, B.; Kaneko, H.; Hirayama, K.; Katayama-Hirayama, K. Municipal solid waste management in Phnom Penh, capital city of Cambodia. Waste Manag. Res. 2011, 29, 491-500.

16. Talyan, V.; Dahiya, R.P.; Sreekrishnan, T.R. State of municipal solid waste management in Delhi, the capital of India. Waste Manag. 2008, 28, 1276-1287.

17. Zhen-shan, L.; Lei, Y.; Xiao-Yan, Q.; Yu-mei, S. Municipal solid waste management in Beijing City. Waste Manag. 2009, 29, 2596-2599.

18. ThaiPublica. National Argenda of Solid Waste, 2014th ed.; ThaiPublica: Bangkok, Thailand, 2014.

19. IPCC. Good Practice Guidance and Uncertainty Management in National Greenhouse Gas Inventories; IGES: Kanagawa, Japan, 2000.

20. Eisted, R.; Larsen, A.W.; Christensen, T.H. Collection, transfer and transport of waste: Accounting of greenhouse gases and global warming contribution. Waste Manag. Res. 2009, 27, 738-745.

21. Tabata, T.; Hishinuma, T.; Ihara, T.; Genchi, Y. Life cycle assessment of integrated municipal solid waste management systems, taking account of climate change and landfill shortage trade-off problems. Waste Manag. Res. 2011, 29, 423-432.

22. IPCC. 2006 IPCC Guidelines for National Greenhouse Gas Inventories; IGES: Kanagawa, Japan, 2006.

23. Manfredi, S.; Tonini, D.; Christensen, T.H.; Scharff, H. Landfilling of waste: Accounting of greenhouse gases and global warming contributions. Waste Manag. Res. 2009, 27, 825-836.

24. Ngnikam, E.; Tanawa, E.; Rousseaux, P.; Riedacker, A.; Gourdon, R. Evaluation of the potentialities to reduce greenhouse gases (GHG) emissions resulting from various treatments of municipal solid wastes (MSW) in moist tropical climates: Application to Yaounde. Waste Manag. Res. 2002, 20, 501-513.

25. Lombardi, L.; Carnevale, E.; Corti, A. Greenhouse effect reduction and energy recovery from waste landfill. Energy 2006, 31, 3208-3219.

26. Ritzkowski, M.; Stegmann, R. Landfill aeration worldwide: Concepts, indications and findings. Waste Manag. 2012, 32, 1411-1419.

27. Larsen, A.W.; Vrgoc, M.; Christensen, T.H.; Lieberknecht, P. Diesel consumption in waste collection and transport and its environmental significance. Waste Manag. Res. 2009, 27, 652-659.

28. Kong, D.; Shan, J.; Iacoboni, M.; Maguin, S.R. Evaluating greenhouse gas impacts of organic waste management options using life cycle assessment. Waste Manag. Res. 2012, 30, 800-812. 
29. Kurniawan, T.A.; Puppim de Oliveira, J.; Premakumara, D.G.J.; Nagaishi, M. City-to-city level cooperation for generating urban co-benefits: The case of technological cooperation in the waste sector between Surabaya (Indonesia) and Kitakyushu (Japan). J. Clean. Product. 2013, 58, 43-50.

30. Solomon, S. Climate Change 2007-The Physical Science Basis: Working Group I Contribution to the Fourth Assessment Report of the IPCC; Cambridge University Press: Cambridge, UK, 2007; Volume 4.

31. Eriksson, O.; Carlsson Reich, M.; Frostell, B.; Björklund, A.; Assefa, G.; Sundqvist, J.O.; Granath, J.; Baky, A.; Thyselius, L. Municipal solid waste management from a systems perspective. J. Clean. Product. 2005, 13, 241-252.

32. Vellini, M.; Savioli, M. Energy and environmental analysis of glass container production and recycling. Energy 2009, 34, 2137-2143.

33. Reh, L. Challenges for process industries in recycling. China Particuol. 2006, 4, 47-59.

34. Cunningham, C.E.; Bremner, R.; Boyle, M. Large Group Community-Based Parenting Programs for Families of Preschoolers at Risk for Disruptive Behaviour Disorders: Utilization, Cost Effectiveness, and Outcome. J. Child Psychol. Psychiatry 1995, 36, 1141-1159.

35. McKenzie-Mohr, D. New Ways to Promote Proenvironmental Behavior: Promoting Sustainable Behavior: An Introduction to Community-Based Social Marketing. J. Soc. Issues 2000, 56, 543-554.

36. Liddle, E.S.; Mager, S.M.; Nel, E.L. The importance of community-based informal water supply systems in the developing world and the need for formal sector support. Geogr. J. 2014, doi:10.1111/geoj.12117.

37. Dewan, C.; Mukherji, A.; Buisson, M.-C. Evolution of water management in coastal Bangladesh: from temporary earthen embankments to depoliticized community-managed polders. Water Int. 2015, doi:10.1080/02508060.2015.1025196.

38. Margerum, R.D.; Robinson, C.J. Collaborative partnerships and the challenges for sustainable water management. Curr. Opin. Environ. Sustain. 2015, 12, 53-58.

39. Sharma, S.K.; Deml, K.; Dangal, S.; Rana, E.; Madigan, S. REDD+ framework with integrated measurement, reporting and verification system for Community Based Forest Management Systems (CBFMS) in Nepal. Curr. Opin. Environ. Sustain. 2015, 14, 17-27.

40. Cagalanan, D. Governance Challenges in Community-Based Forest Management in the Philippines. Soc. Nat. Resour. 2015, 28, 609-624.

41. Wallerstein, N.B.; Duran, B. Using Community-Based Participatory Research to Address Health Disparities. Health Promot. Pract. 2006, 7, 312-323.

42. Farmer, P.; Léandre, F.; Mukherjee, J.; Gupta, R.; Tarter, L.; Kim, J.Y. Community-based treatment of advanced HIV disease: Introducing DOT-HAART (directly observed therapy with highly active antiretroviral therapy). Bull. World Health Organ. 2001, 79, 1145-1151.

43. Afroz, R.; Hanaki, K.; Hasegawa-Kurisu, K. Willingness to pay for waste management improvement in Dhaka city, Bangladesh. J. Environ. Manag. 2009, 90, 492-503.

44. Wilson, D.C.; Velis, C.; Cheeseman, C. Role of informal sector recycling in waste management in developing countries. Habitat Int. 2006, 30, 797-808.

45. Medina, M. The Informal Recycling Sector in Developing Countries: Organizing Waste Pickers to Enhance Their Impact; World Bank: Washington, DC, USA, 2008. 
46. Afroz, R.; Hanaki, K.; Tuddin, R.; Ayup, K. A survey of recycling behaviour in households in Dhaka, Bangladesh. Waste Manag. Res. 2010, 28, 552-560.

47. Scheinberg, A.; Spies, S.; Simpson, M.H.; Mol, A.P.J. Assessing urban recycling in low- and middle-income countries: Building on modernised mixtures. Habitat Int. 2011, 35, 188-198.

48. Mongkolnchaiarunya, J. Promoting a community-based solid-waste management initiative in local government: Yala municipality, Thailand. Habitat Int. 2005, 29, 27-40.

49. Suttibak, S.; Nitivattananon, V. Assessment of factors influencing the performance of solid waste recycling programs. Resourc. Conserv. Recycl. 2008, 53, 45-56.

50. Nzeadibe, T.C. Solid waste reforms and informal recycling in Enugu urban area, Nigeria. Habitat Int. 2009, 33, 93-99.

51. Xu, W.; Zhou, C.; Lan, Y.; Jin, J.; Cao, A. An incentive-based source separation model for sustainable municipal solid waste management in China. Waste Manag. Res. 2015, 33, 469-476.

52. Colon, M.; Fawcett, B. Community-based household waste management: Lessons learnt from EXNORA's "zero waste management" scheme in two South Indian cities. Habitat Int. 2006, 30, 916-931.

53. Rayong City Municipality. 2012 Report of Waste Bank Operation; Rayong City Municipality: Rayong, Thailand, 2013; p. 8.

54. Athitanun, P. Green Biz Generation Going Green: Sustainable Development; NSTDA Academy: Bangkok, Thailand, 2011.

55. Browne, D.; O’Regan, B.; Moles, R. Use of carbon footprinting to explore alternative household waste policy scenarios in an Irish city-region. Resourc. Conserv. Recycl. 2009, 54, 113-122.

56. TGO. Guideline for Carbon Footprint Estimation in Local Administration Entities, 1st ed.; TGO: Bangkok, Thailand, 2011.

57. PCD. Survey and Analysis of Municipal Solid Waste Characteristics of all Municiplaities in Thailand; PCD: Bangkok, Thailand, 2004.

58. AIT-UNEP. Municipal Waste Management Report: Status-Quo and Issues in Southeast and East Asian Countries; AIT-UNEP: Pathumthani, Thailand, 2010.

59. Thailand's Regional Environmental Office 14. Report of Municipal Wastewater Treatment and Solid Waste Management System for the Tapi Wastershed; Thailand's Regional Environmental Office 14: Surat Thani, Thailand, 2012.

60. Thailand's Regional Environmental Office 9. Environmental Situation Report 2012 (B.E. 2555); Srisawa, C., Ed.; Thailand's Regional Environmental Office 9: Phang Khon, Thailand, 2013.

61. Jenkins, R.R.; Martinez, S.A.; Palmer, K.; Podolsky, M.J. The determinants of household recycling: a material-specific analysis of recycling program features and unit pricing. J. Environ. Econ. Manag. 2003, 45, 294-318.

62. Puangsiri, S. Carbon Accounting System from Integrated Municipal Waste Management in Thailand: Case Study Sakhonnakhon Province; Chulalongkorn University: Bangkok, Thailand, 2010.

63. Timlett, R.E.; Williams, I.D. Public participation and recycling performance in England: A comparison of tools for behaviour change. Resourc. Conserv. Recycl. 2008, 52, 622-634.

64. Seik, F.T. Recycling of domestic waste: Early experiences in Singapore. Habitat Int. 1997, 21, 277-289. 
65. Menikpura, S.N.M.; Sang-Arun, J.; Bengtsson, M. Integrated Solid Waste Management: An approach for enhancing climate co-benefits through resource recovery. J. Clean. Product. 2013, $58,34-42$.

66. Menikpura, S.N.M.; Gheewala, S.H.; Bonnet, S.; Chiemchaisri, C. Evaluation of the Effect of Recycling on Sustainability of Municipal Solid Waste Management in Thailand. Waste Biomass Valorization 2012, 4, 237-257.

67. United Nations. World Urbanization Prospects: The 2014 Revision; Department of Economic and Social Affairs: New York, NY, USA, 2014.

(C) 2015 by the authors; licensee MDPI, Basel, Switzerland. This article is an open access article distributed under the terms and conditions of the Creative Commons Attribution license (http://creativecommons.org/licenses/by/4.0/). 